\title{
PENGARUH RANGE OF MOTION INTRADIALISIS TERHADAP UREA REDUCTION RATIO PADA PASIEN HEMODIALISA
}

\author{
Danny Putri Sulistyaningrum ${ }^{1}$, l'ien Noer'aini $^{2}$ \\ ${ }^{1}$ STIKES Telogorejo Semarang, Indonesia \\ ${ }^{2}$ Program Studi D-3 Keperawatan \\ Email : danny_putri@stikestelogorejo.ac.id, iiennoeraini@stikestelogorejo.ac.id
}

\begin{abstract}
A B S T R A K
Hemodialisa merupakan terapi pengganti ginjal yang bertujuan membuang sisa pembongkaran tubuh melalui mesin dialisis. Namun, banyak pasien dialisis mengalami gejala seperti kelemahan, keletihan, dan kurang berenergi. Hal ini dapat disebabkan oleh beberapa faktor, salah satunya adekuasi hemodialisa yang kurang efektif. Adekuasi hemodialisa merupakan indikator keberhasilan dialisis yang dapat dinilai dengan urea reduction ratio (URR). Range of motion (ROM) intradialisis adalah salah satu intervensi keperawatan yang mampu meningkatkan bersihan sisa pembongkaran tubuh. Penelitian ini bertujuan untuk mengidentifikasi pengaruh ROM intradialisis terhadap urea reduction ratio pada pasien hemodialisa. Jenis penelitian ini menggunakan quasi experiment, dengan rancangan pre - post test with control group yang melibatkan 32 responden melalui teknik consecutive sampling. Analisis statistik dalam penelitian ini menggunakan uji Mann Whitney. Hasil penelitian menunjukkan tidak ada pengaruh ROM intradialisis terhadap urea reduction ratio pada pasien hemodialisa $(p=0.955 ; \alpha=0.05)$. Pada dasarnya latihan intradialisis yang dilakukan 2 bulan atau lebih dengan durasi 30 menit selama 3 kali seminggu secara rutin dapat mempengaruhi urea reduction ratio. Untuk penelitian selanjutnya, diharapkan intervensi ini tidak hanya dilakukan dalam satu kali pengamatan sehingga akan memberikan hasil yang optimal.
\end{abstract}

Kata Kunci : Hemodialisa, Range of motion intradialisis, Ureum, Urea Reduction Ratio

\section{PENDAHULUAN}

Hemodialisa merupakan serangkaian proses pengoreksian dan pembuangan sisa metabolisme tubuh melalui mesin dialisis bagi pasien gagal ginjal terminal. Angka kejadian jumlah pasien hemodialisa terus meningkat. Jumlah pasien hemodialisa di Amerika Serikat tahun 2017 meningkat sebanyak $86.9 \%$ (USRDS, 2019). Jumlah pasien hemodialisa di Indonesia tahun 2018 meningkat sebanyak 92\% menjadi 66433 *Corresponding Author :

\section{Danny Putri Sulistyaningrum}

STIKES Telogorejo Semarang, Indonesia Email : danny_putri@ stikestelogorejo.ac.id pasien (IRR, 2018). Sementara jumlah pasien hemodialisa di Jawa Tengah sebanyak 7906 pasien (IRR, 2019).

Hemodialisa bertujuan untuk membuang kelebihan cairan, elektrolit, maupun toksin tubuh. Namun seringkali pasien merasakan gejala seperti kelelahan, kelemahan, dan kurang berenergi yang dirasakan diakhir sesi dialisis (Gordon et al., 2011; Artom et al., 2014). Hal ini terjadi akibat adekuasi hemodialisa yang tidak 
adekuat sehingga akumulasi sampah metabolik tertumpuk di vaskular (Mahrova \& Svagrova, 2013; Ladesvita, 2016).

Keberhasilan suatu dialisis disebut dengan adekuasi hemodialisa yang dapat diukur dengan menggunakan urea reduction ratio (URR). Dikatakan efektif jika nilai URR minimal 65\% (NKF, 2015). Prinsip untuk membuang bersihan sisa metabolisme yaitu dengan meningkatkan perfusi. Range of motion (ROM) intradialisis adalah intervensi keperawatan yang efektif untuk meningkatkan bersihan urea (Mohamed \& Soliman, 2015; Ladesvita, 2016).

Jawa Tengah memiliki berbagai pelayanan fasilitas hemodialisa, salah satunya Klinik Ginjal dan Hipertensi Lestari yang berada di kota Semarang. Hemodialisis dilakukan dengan durasi rata - rata 4 jam selam 2 kali seminggu. Berdasarkan hasil studi pendahuluan, sebagian besar pasien mengeluh lelah, lemah, dan kurang berenergi di akhir sesi dialisis. Berdasarkan uraian diatas, penulis tertarik melakukan penelitian tentang "Pengaruh Range Of Motion Intradialisis Terhadap Urea Reduction Ratio Pada Pasien Hemodialisa di Klinik Ginjal dan Hipertensi Lestari”.

\section{METODE PENELITIAN}

Desain penelitian ini menggunakan quasi experiment dengan rancangan pre -

\section{*Corresponding Author :}

\section{Danny Putri Sulistyaningrum}

STIKES Telogorejo Semarang, Indonesia Email : danny_putri@ stikestelogorejo.ac.id post test with control group. Populasi penelitian ini adalah semua pasien hemodialisa di Klinik Ginjal dan Hipertensi Lestari Semarang dengan total sampel 32 responden yang dipilih menggunakan consecutive sampling. Kriteria inklusi terdiri dari usia 25 - 70 tahun, kesadaran komposmentis, mampu membaca dan menulis, bersedia menjadi responden, menjalani hemodialisa secara rutin 2 kali seminggu minimal 4 jam. Sementara kriteria eksklusi terdiri dari pasien dengan gangguan hemodinamik, gangguan muskuloskeletal, dann mengalami angina pektoris tidak stabil, gagal jantung, emboli paru akut, infark miokard akut, maupun miokarditis.

Responden dibagi menjadi 16 kelompok perlakuan dan 16 kelompok kontrol. Sebelum dialisis, responden dilakukan pengambilan sampel darah dan diukur tanda vitalnya. Pada kelompok perlakuan, 2 jam sesi pertama dialisis diberikan intervensi ROM selama 15 menit pada ekstremitas atas dan bawah (terkecuali ektremitas yang terpasang akses dialisis), sementara pada kelompok kontrol hanya melakukan terapi dialisis saja. Selanjutnya diakhir sesi dialisis dilakukan pengambilan sampel darah dan diukur tanda vitalnya kembali. Rumus urea reduction ratio (URR) $=100 \% \times[1-$ (ureum postdialisis / ureum predialisis)]. 
Analisis data menggunakan SPSS 16.0, dimana analisis bivariat menggunakan uji Mann Whitney.

\section{HASIL PENELITIAN DAN PEMBAHASAN HASIL PENELITIAN}

Hasil analisis univariat diperoleh hasil bahwa mean usia responden adalah 53.78 tahun. Hasil penelitian ini sejalan dengan data IRR (2018) yang mengatakan bahwa usia pasien hemodialisa terbanyak pada kelompok usia 45 - 54 tahun. Sementara data URSDS (2019) mengatakan bahwa usia pasien hemodialisa terbanyak pada kelompok usia 45 - 64 tahun. Laju filtrasi glomerulus akan mengalami penurunan dan ginjal akan kehilangan fungsi $50 \%$ apabila usia seseorang melewati 40 tahun (Smeltzer \& Bare, 2010; Nitta el al., 2014).

Distribusi karakteristik responden bahwa sebagian besar responden berjenis kelamin laki - laki (59.38\%). Hasil penelitian ini sejalan dengan data IRR (2018) yang mengatakan bahwa pasien hemodialisa terbanyak berjenis kelamin laki - laki (57\%). Hal ini juga didukung data URSDS (2019) bahwa pasien hemodialisa terbanyak berjenis kelamin laki - laki. Peneliti Nurchayati (2011), Hallan \& Orth (2011), dan Vendramini et al (2012) mengatakan bahwa laki - laki cenderung memiliki kebiasaan minum kopi atau alkohol dan merokok.

\section{*Corresponding Author :}

\section{Danny Putri Sulistyaningrum}

STIKES Telogorejo Semarang, Indonesia Email : danny_putri@ stikestelogorejo.ac.id
Kebiasaan tersebut akan mengaktivasi sistem saraf simpatis dan menyebabkan hipertensi. Selanjutnya hipertensi yang berkepanjangan mengakibatkan rusaknya nefron pada ginjal dan mencetuskan terjadinya gagal ginjal terminal (Black \& Hawks, 2014).

Pada analisis bivariat diperoleh hasil bahwa tidak terdapat pengaruh urea reduction ratio yang bermakna antara kelompok kontrol dan perlakuan setelah dilakukan ROM intradialisis ( $p>0.05$ ). Hal ini didukung oleh penelitian Orcy et al (2014) dengan melakukan cycle ergometer 60 menit pada 2 jam pertama sesi hemodialisa selama kurang lebih 11 bulan tidak berpengaruh pada bersihan ureum dan adekuasi hemodialisa. Selain itu penelitian Musavian et al (2015) dengan melakukan bicycle ergometer baik aktif maupun pasif 30 menit pada 2 jam pertama sesi hemodialisa selama 2 bulan tidak berpengaruh pada adekuasi hemodialisa.

Adekuasi hemodialisa yang baik harus dievaluasi minimal satu bulan sekali dengan menilai ureum pre dialisis dan post dialisis. Pada prinsipnya latihan intradialisis dianjurkan untuk dilakukan minimal 2 bulan dengan durasi 30 menit selama 3 kali seminggu secara rutin sehingga dapat meningkatkan adekuasi hemodialisa. Hal ini didukung oleh penelitian Vaithilingam (2004) bahwa latihan intradialisis harus dilakukan 
secara rutin selama dua bulan atau lebih selama hemodialisis untuk meningkatkan bersian urea dan efikasi dialisis. Parker et al (2015) juga mengatakan dengan melakukan intradialytic bicycling 30 menit pada 2 jam pertama sesi hemodialisa selama 6 bulan mampu meningkatkan nilai URR.

ROM menimbulkan kontraksi otot dan meningkatkan terjadinya tekanan gradien di otot. Selanjutnya timbul fluktuasi pada aliran darah dalam otot sehingga jarak difus pembuluh darah mengalami pemendekan. Hal ini meningkatkan luas permukaan kapiler otot dan terjadinya pertukaran oksigen sehingga pembuangan toksik metabolisme lebih maksimal (Boundless, 2016).

\section{SIMPULAN}

Pada penelitian ini diperoleh mean usia responden 53.78 tahun dan sebagian besar berjenis kelamin laki - laki (59.38\%). Hasil analisis diperoleh kesimpulan tidak ada pengaruh Range of Motion terhadap urea reduction ratio pada pasien hemodialisa.

\section{SARAN}

Untuk penelitian selanjutnya, diharapkan intervensi ini tidak hanya dilakukan dalam satu kali pengamatan sehingga akan memberikan hasil yang optimal.

\section{*Corresponding Author :}

\section{Danny Putri Sulistyaningrum}

STIKES Telogorejo Semarang, Indonesia Email : danny_putri@ stikestelogorejo.ac.id

\section{DAFTAR PUSTAKA}

Artom, M., Moss-morris, R., Caskey, F., \& Chilcot, J. (2014). Fatigue in advanced kidney disease. Kidney International, 86, 497-505. doi:10.1038/ki.2014.86.

Black, J \& Hawks, J. (2014). Keperawatan medikal bedah: manajemen klinis untuk hasil yang diharapkan. Jakarta: Salemba.

Boundless. (2016). Blood flow to an active muscle changes depending on exercise intensity and contraction frequency and rate. https://www.boundless.com/physiolo gy/textbooks/ boundless-anatomyand-physiologytextbook/cardiovascular-systemblood-vessels-19/blood-flow-throughthe-body-185/blood-flow-in-skeletalmuscle-921-5579/

Gordon, P. L., Doyle, J. W., \& Johansen, K. L. (2011). Postdialysis fatigue is associated with sedentary behavior. Clinical Nephrology, 75, 426-433.

Hallan, S. I., \& Orth, S. R. (2011). Smoking is a risk factor in the progression to kidney failure. Kidney International, 
80 ,

$516-523$.

doi:10.1038/ki.2011.157.

Indonesian Registry Renal / IRR. (2018). $11 \mathrm{~h}$ Report Of Indonesian Renal Registry 2018.

https://www.indonesianrenalregistry.

\section{org/data/IRR\%202018.pdf}

Ladesvita, F. (2016). Perbandingan efektifitas latihan range of motion (ROM) dengan latihan pedal intradialisis terhadap adekuasi hemodialisa pada pasien hemodialisa kronik. Tesis. Fakultas IImu Keperawatan Universitas Indonesia: Tidak dipublikasikan.

Mahrova, A., \& Svagrova, K. (2013). Exercise therapy - additional tool for managing physical and psychological problems on hemodialysis. doi:10.5772/53058.

Mohamed, H., \& Soliman, M. (2015). Effect of intradialytic exercise on fatigue, electrolytes level and blood pressure in hemodialysis patients: a randomized controlled trial. Journal of Nursing Education and Practice, 5, 16-28. doi:10.5430/jnep.v5n11p16.

Musavian, A., Soleimani, A., Masoudi, A., Baseri, A., Savari, F. (2015). Comparing the effects of active and passive intradialytic pedaling

\section{*Corresponding Author :}

\section{Danny Putri Sulistyaningrum}

STIKES Telogorejo Semarang, Indonesia Email : danny_putri@ stikestelogorejo.ac.id exercises on dialysis efficacy, electrolytes, hemoglobin, hematocrit, blood pressure and health-related quality of life. Nurs Midwifery Stud, 4(1):e25922.

doi:10.17795/nmsjournal25922

National Kidney Foundation. (2015). KDOQI Clinical Practice Guideline Hemodialysis Adequacy : 2015 Update.

https://www.ajkd.org/article/S02726386(15)01019-7/fulltext

Nitta, K., Okada, K., Yanai, M., \& Takahashi, S. (2014). Aging and chronic kidney disease. Kidney Blood Press Res, 8666 , $109-120$. doi:10.1159/000355760.

Nurchayati, S. (2011). Analisis faktor - faktor yang berhubungan dengan kualitas hidup pasien penyakit ginjal kronik yang menjalani hemodialisis di Rumah Sakit Islam Fatimah Cilacap dan Rumah Sakit Umum Daerah Banyumas. Tesis. Fakultas IImu Keperawatan Universitas Indonesia: Tidak dipublikasikan.

Orcy, R., Antunes, M. F., Schiller, T., Seus, T., \& Böhlke, M. (2014). Aerobic exercise increases phosphate removal during hemodialysis: A controlled trial. Hemodialysis 
International, 18(2), 450-458. doi:10.1111/hdi.12123
45, 834-840. doi:10.1590/S0100$879 \times 2012007500120$

Parker, K., Zhang, X., Lewin, A., \& MacRae,

J. M. (2015). The association between intradialytic exercise and hospital usage among hemodialysis patients. Applied Physiology, Nutrition, and Metabolism, 40(4), 371-378. doi:10.1139/apnm-20140326

Smeltzer, S. C. \& Bare, B. G. (2010). Brunner and suddarth's texbook of medical surgical nursing. Lippincott: Philadelphia.

United States Renal Data System / USRDS. (2019). US Data Renal System 2019 Annual Data Report : Epidemiology of Kidney Disease in the United States. https://www.usrds.org/2019/view/US RDS 2019 ES final.pdf

Vaithilingam I., Polkinghorne, K., Atkins, R., Kerr, P. (2004). Time and exercise improve phosphate removal in hemodialysis patients. Am J Kidney Dis, 43(1):85-9. doi: 10.1053/j.ajkd.2003.09.016

Vendramini, L. C., Nishiura, J. L., Baxmann, A. C., \& Heilberg, I. P. (2012). Caffeine intake by patients with autosomal dominant polycystic kidney disease. Braz J Med Biol Res,

*Corresponding Author :

Danny Putri Sulistyaningrum

STIKES Telogorejo Semarang, Indonesia Email : danny_putri@ stikestelogorejo.ac.id 